\title{
IMPACTOS NA LAGOA DE ARARUAMA E PERCEPÇÃO AMBIEN- TAL DA COMUNIDADE DA PRAIA DO SIQUEIRA, CABO FRIO (RJ)
}

Rafaela Machado de Almeida Schuindt ${ }^{1}$

Renata da Silva Daco ${ }^{2}$ Manildo Marcião de Oliveira ${ }^{3}$

Resumo: A Lagoa de Araruama (LA) é a maior laguna hipersalina do mundo e está localizada no sudeste do Brasil, no estado do Rio de Janeiro. O objetivo deste trabalho foi identificar alguns impactos sofridos pela LA no município de Cabo Frio, através da percepção da comunidade da Praia do Siqueira. Foram realizadas quatro etapas no trabalho: avaliação físico-química, avaliação microbiológica, registro fotográfico com relatório da visita guiada e entrevista direcionada. Os resultados mostraram a alteração de importantes parâmetros ambientais (potencial redox e microbiológico) reafirmando os impactos que a laguna vem sofrendo nas últimas décadas comprometendo assim as atividades de pesca e lazer. O estudo propõe a ações de Educação Ambiental e o fortalecimento da organização comunitária.

Palavras-chave: Lagoa de Araruama; Impacto Ambiental; Educação Ambiental.

1 Especialista em Educação Ambiental pelo Instituto Federal de Educação, Ciência e Tecnologia Fluminense Campus Cabo Frio. Mestranda em Ciências Ambientais e Conservação pelo PPGCiAC/UFRJ. E-mail: rafaelamachadobio@gmail.com

2 Mestre em Ciência Ambiental pela UFF. E-mail: manildodpicf@gmail.com

3 Doutor em Ciências pela UERJ e Prof. ํ Coordenador do Laboratório de Ecotoxicologia e Microbiologia Ambiental (LEMAM) do Instituto Federal de Educação, Ciência e Tecnologia Fluminense Campus Cabo Frio... E-mail: rsdaco@gmail.com 


\section{Introdução}

As lagoas costeiras estão por toda a extensão da costa continental e são identificadas como corpos de água lênticos de importância na biodiversidade natural e para muitos segmentos da sociedade (ESTEVES et al., 2008, p. 968973).

A Lagoa de Araruama com seus $220 \mathrm{~km}^{2}$ é a maior laguna hipersalina em estado permanente no mundo e com tal relevância requer cuidados com sua preservação (BIDEGAIN, 2002, p. 11; CILSJ, 2005, p.46). A laguna encontra-se no sudeste do Brasil, no estado do Rio de Janeiro, na qual estende em seis municípios, sendo eles: Saquarema, Araruama, Iguaba Grande, São Pedro da Aldeia, Arraial do Cabo e Cabo Frio, neste último município a laguna possui uma ligação com o mar através do canal de Itajurú (CARVALHO et al., 2014, p. 2).

A origem do nome Lagoa de Araruama foi avaliada por Souza et al. (2011, p. 10) sendo um nome geográfico onde o termo "Lagoa" concernente à natureza hidrográfica e o termo "Araruama" pela descrição da paisagem realizada pelos índios tupi habitantes da costa brasileira no século de XVI, no qual significava "Terra dos Papagaios".

A Praia do Siqueira objeto do atual estudo, fica localizada na cidade de Cabo Frio que compreende uma península de areia com a largura mínima de 400 metros, entre o Oceano Atlântico e a Lagoa de Araruama. Tal posicionamento permite o nascer do sol na beira mar e o pôr do sol na laguna, estes acontecimentos associados com a beleza natural do local proporcionam atrativas paisagens turísticas para o município (BERANGER, 2003, p.39-40). Em Cabo Frio além do bairro Praia do Siqueira, os bairros vizinhos Palmeiras e Portinho também circundam a laguna.

O Consórcio Intermunicipal Lagos São João - CILSJ (CILSJ, 2005, p. 46) em seu estudo informa a relação dos rios das Moças, rio Congo, rio Mataruna, rio do Cortiço, rio Salgado, rio Iguaçaba, rio Úba, as valas dos Barretos e do Hospício, o riacho Cândido, córrego Piripiri, e os canais do Mossoró, do Parati, da Cia Nacional da Álcalis, da Praia do Siqueira e do Excelsior, para a formação de um conjunto de pequenas sub-bacias que pertencem a bacia hidrográfica da LA.

Lima et al. (2014, p.1) relata que a Lagoa de Araruama é um dos corpos d'água costeiros do Estado do Rio de Janeiro que vêm sofrendo perda na sua qualidade ambiental devido as intervenções antrópicas, como o aumento populacional nas regiões litorâneas e consequentemente o aumento de resíduos orgânicos liberados na laguna. A LA também detém um histórico com a extração de sal, extração de conchas, pesca artesanal e turismo (CILSJ, 2005, p. 133).

A frequência do lançamento destes resíduos no ambiente aquático reflete na redução da salinidade e em um expressivo aumento de nutrientes, especialmente fósforo e nitrogênio, ocasionando a eutrofização cultural (CARVALHO et al., 2014, p. 2; BERTUCCl et al., 2016, p. 49). 
Quando o grau de eutrofização está elevado podem ocorrer alterações no ecossistema lagunar como: diminuição na variedade de espécies, e/ou invasão de espécies exóticas, essas alterações sucede na LA com o aumento da biomassa das algas, assim como dos sulfetos e nitritos, e diminuindo o oxigênio dissolvido, efeitos estes prejudiciais a biodiversidade aquática (MOREIRA, 2017, p. 3).

Segundo Pereira (2007, p. 2), a situação é agravada na década de 60 com um aumento na ocupação do solo da bacia da laguna de Araruama, devido à implantação de diversos loteamentos e condomínios sem a devida preocupação com a infraestrutura sanitária.

A liberação de efluentes domésticos na laguna sem o tratamento adequado e o aporte artificial de água doce influencia no balanço hídrico, na densidade da fauna e flora, e nas atividades antrópicas desenvolvidas na LA (BERTUCCl et al., 2016, p. 44).

Esta situação não se retém ao impacto ambiental, causa desconforto para a sociedade que ali reside e aos turistas que visitam o local, devido a poluição visual do ambiente e ao cheiro desagradável das algas em decomposição (LIMA et al.,2014, p. 4; PEREIRA, 2007, p. 4).

Segundo Cristiane (2015) o secretário de meio ambiente de Cabo Frio respondendo a críticas da população relatou a situação da Lagoa de Araruama, disse que piorou a situação depois de 2007 devido ao histórico de despejo in natura de esgoto na laguna e que resultado foi a superpopulação de algas.

Tais alterações ambientais influenciam na relação social, provocando assim uma sensibilização com a questão ambiental como é discutido em Ribeiro et al. (2010, p. 7), surgindo a necessidade de implementar a Educação Ambiental (EA) em espaços no qual o homem se preocupa com o meio onde vive (FERREIRA, 2006, p.2).

As atividades de EA são asseguradas pela Política Nacional de Educação Ambiental, Lei no 9.795 de 27 de abril de 1999, capítulo 1 da Educação Ambiental:

Art. 10 Entendem-se por educação ambiental os processos por meio dos quais o indivíduo e a coletividade constroem valores sociais, conhecimentos, habilidades, atitudes e competências voltadas para a conservação do meio ambiente, bem de uso comum do povo, essencial à sadia qualidade de vida e sua sustentabilidade.

Art. 2 A educação ambiental é um componente essencial e permanente da educação nacional, devendo estar presente, de forma articulada, em todos os níveis e modalidades do processo educativo, em caráter formal e não-formal (Brasil, 1999, p. 1). 
Silva (2013, p. 53) argumenta que os debates sobre os danos ambientais são lutas pela intervenção da população na natureza e da política na gestão do Meio Ambiente.

Em sua pesquisa Porcher et al. (2010, p. 62) retrata a realidade dos impactos ambientais na Lagoa de Bacopari, no município de Mostardas (RS), onde nos meses de verão com o aumento da população e concomitante da poluição devido ao turismo são intensificados os conflitos sociais e ambientais, visto que as comunidades são compostas por pescadores e agricultores de arroz. Nos municípios que permeiam a Lagoa de Araruama a população chega a duplicar no verão e em feriados estirados com a presença dos turistas (BERTUCCl et al., 2016, p. 44).

A efetivação da EA permite que os cidadãos possam compreender de forma holística o contexto no qual estão inseridos, ou seja, identificar a organização social, os sujeitos e os atores envolvidos buscando desfrutar dos recursos naturais visando alcançar os desejos espirituais e materiais, sem comprometer o desenvolvimento socioambiental ao longo dos anos (DIAS, 2004, p. 99).

Conforme Dias (2004, p. 99) para a implementação dessa visão é necessário realizar a formação, capacitação e interação do grupo no qual for desenvolvido, pensando de forma local, regional ou nacional, mas levando em conta a situação global. Bem mais do que uma mudança de comportamento dos sujeitos envolvidos na práxis educativa devemos promover uma mudança de atitude (LOUREIRO, 2012, p. 65).

No estudo realizado por Ribeiro et al. (2010, p. 8), os impactos identificados através de entrevistas em Cabo Frio obtiveram um consenso sobre os danos ao ecossistema marinho e questões como o despejo de detritos e esgoto foram ressaltados.

Em um determinado momento a elevada produtividade primária favoreceu o desenvolvimento da biomassa de peixes e concomitantemente a atividade pesqueira, na qual desenvolveu uma sobrepesca (BERTUCCI et al., 2016, p. 50).

Em entrevistas com os pescadores artesanais eles avaliaram que suas práticas de pesca não são consideradas como predatórias: o uso de rede de arrasto no fundo da lagoa, o uso de malha fina inadequada e a pesca realizada no período do defeso, sendo as duas últimas proibidas por lei (RIBEIRO et al, 2010, p. 8).

Bertucci et al. (2016, p. 51) observa o início da preservação da laguna pelo estado e sociedade civil quando se organizaram para o monitoramento da LA, como o começo das criações das a Áreas de Preservação Ambiental (APAs) na região, como a APA de Massambaba e posteriori em 1999 a criação do Consórcio Intermunicipal Lagos São João (CILSJ).

Desta forma existe a necessidade de consultar a população residente do local para identificar os possíveis impactos sofridos na laguna. $E$ a partir da percepção, desenvolver junto ao grupo (de forma dialogada) práticas reflexivas

Revbea, São Paulo, V,13, № 1: 299-321, 2018. 
de educação ambiental, visando minimizar ações de degradação ambiental no ecossistema lagunar, de acordo com Ferreira (2006, p. 2).

\section{Histórico local}

O nome do bairro Praia do Siqueira surgiu por volta de 100 anos atrás, anteriormente o local era chamado de Baixo Pequeno. Esta alteração ocorreu em alusão ao poço de água potável feito na época por um morador antigo conhecido como "Velho Siqueira".

Os moradores contam a história como se fosse uma lenda do local e descrevem o episódio para todos que tem interesse sobre a Praia do Siqueira:

No quintal do velho Siqueira existia um grande tronco de Jacarandá na qual estava à frente de sua casa e o incomodava todos os dias. Siqueira então cavou em volta do tronco frondoso e pediu a ajuda do senhor Luiz Borges para a retirada. Seu companheiro então levou seus pescadores, cordas e estacas na qual amarraram o tronco e puxaram com toda força. Ao puxarem o tronco o espigão central abriu um buraco no meio, que jorrou um feixe de água muito forte no qual escorria para um brejo ao lado. O senhor Siqueira, pôs uma barricada no feixe de água formando assim um poço. A água do poço era saborosa na qual servia para beber, cozinhar e lavar roupa, atendendo toda a região como a Ponta do Ambrósio, Baixo Grande, Porto do Carro, Campo Redondo.... O prefeito de Cabo Frio tomando conhecimento do fato mandou um representante ao local para constar a situação, no qual mandou construir um poço de cimento e tijolo maciço no poço do velho Siqueira. A Câmara dos Vereadores se reuniu e resolveram em homenagem ao velho Siqueira mudar o nome do local de Baixo Pequeno para Praia do Siqueira (informação verbal) ${ }^{4}$.

A comunidade da Praia do Siqueira possui $2 \mathrm{~km}$ de orla da laguna e desde a fundação do bairro existe uma grande interação dos moradores com a Lagoa de Araruama. $O$ bairro tradicional de pescadores também possui muitos fiéis católicos. No local existe uma das capelas mais antigas do município, a Capela de São Pedro, sendo este o padroeiro dos pescadores.

A principal pescaria realizada no local é a do camarão rosa, sendo os de maior porte identificado cientificamente com o nome de Penaeus brasiliensis e os de menor porte $P$. paulensis (BIDEGAIN, 2002, p. 69). A pesca na comunidade é realizada nas primeiras horas da noite e utilizam de três apetrechos de pesca distintos: a rede de trolha, a pesca de gancho e a pesca de

\footnotetext{
${ }^{1}$ Informação verbal do senhor Eli Costa morador antigo da Praia do Siqueira, em Cabo Frio, em junho de 2016.
} 
cerco. Na volta da pescaria a comercialização do camarão rosa acontece por meio de um leilão no ponto de pesagem (RIBEIRO et al., 2010, p. 5).

O bairro possui algumas atrações turísticas no qual os visitantes além de apreciarem o belo pôr do sol, podem degustar o saboroso camarão nos quiosques da orla e desfrutarem dos festivais típicos de camarão. A praia já foi mais utilizada para banho de sol, prática de esportes e área de lazer dos jovens, entretanto devido às condições atuais da laguna essas atividades não são aconselháveis e/ou inviáveis, persistindo ainda a pesca, pois é uma importante fonte de renda para muitos moradores locais.

A Lagoa de Araruama possui uma grande relação socioambiental com a população residente no entorno da laguna. Por isso, o estado e a manutenção das características originais da laguna são essenciais para que a comunidade não sofra com os impactos negativos.

A escolha da comunidade Praia do Siqueira foi feita por possuir uma população tradicional de pescadores artesanais e por ser um ponto turístico em Cabo Frio.

Hipótese de trabalho: "A percepção da população com respeito à degradação da Lagoa de Araruama é baseada em conhecimento tácito e não pelo acesso a informação decorrente do poder público".

\section{Objetivos}

Identificar quais os impactos sofridos pela Lagoa de Araruama e qual a percepção do ambiente junto à comunidade da Praia do Siqueira no munícipio de Cabo Frio. Os objetivos específicos são: articulações sociais e ambientais, a fim de integrar o saber científico ao conhecimento popular; analisar a qualidade da água em pontos da Praia do Siqueira e comparar com outro bairro (Palmeiras) na margem da laguna; e fornecer dados para futuras propostas de projetos visando o aumento da percepção da população local com o ambiente.

\section{Metodologia}

O estudo utilizou dos métodos quantitativos e qualitativos combinados em quatro etapas: a) medição dos parâmetros físico-químicos da água, b) coleta de água e análise microbiológica, c) registro fotográfico e visita guiada, e d) entrevista direcionada. Este trabalho configura-se em multimétodo e suas etapas servirão de base para o desenvolvimento do trabalho (FREITAS, et al., 2000, p. 10).

\section{Área de estudo}

A Lagoa de Araruama encontra-se no sudeste do Brasil, em seis municípios do estado do Rio de Janeiro: Saquarema, Araruama, Iguaba Grande, São Pedro da Aldeia, Arraial do Cabo e Cabo Frio (Figura 1). Em Cabo Frio a LA possui a única conexão com o mar pelo canal de Itajurú. 


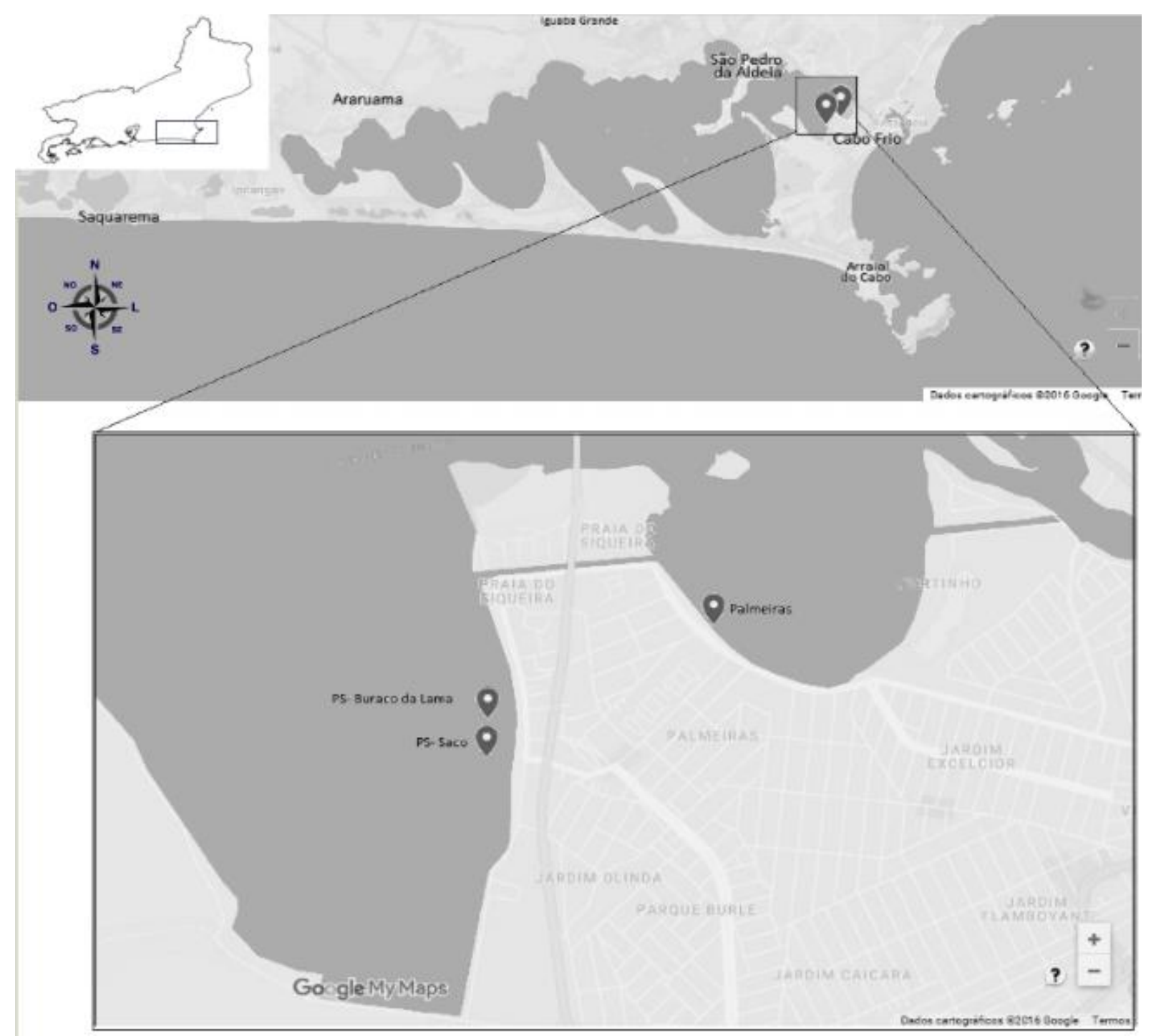

Figura 1: Localização da área da Lagoa de Araruama com a posição dos municípios do entorno e os bairros de estudo demarcado os pontos de análises. Fonte: Adaptado Google My Maps.

A ligação da laguna com o mar consiste no primeiro critério para a identificação do tipo de lagoa costeira, esta interação interfere diretamente na característica geofísica responsável pelo equilíbrio hidrológico do ambiente aquático constantemente afetado pelos processos físicos e o desenvolvimento geomorfológico (ESTEVES et al., 2008, p. 968).

O clima predominante na região é o semiárido, com a média de precipitação na região de $1.000 \mathrm{~mm} / \mathrm{ano}$. Na bacia da Lagoa de Araruama possui um relevo de extensas áreas de colinas de topo arredondado e inferiores a $100 \mathrm{~m}$, sendo a região rica em recursos naturais como: areias, aréolas, cascalhos, saibros, rochas britadas e seixos. Possuem como cobertura vegetal a restinga, a mata atlântica e o tipo arbóreo, e na região da laguna a vegetação manguezal, além de uma rica flora. A região do Consórcio Intermunicipal Lagos São João 
possui uma grande diversidade de espécies viventes, sendo algumas espécies com muitos representantes e outras com pouquíssimos, na LA foram identificadas 39 espécies de peixe e existe uma preocupação com a fauna local (CILSJ, 2005, p. 26-31).

A área de estudo onde foi desenvolvida as metodologias do presente estudo na Lagoa de Araruama estão localizadas no município de Cabo Frio, nos bairros Palmeiras onde teve um ponto de análise e Praia do Siqueira com dois pontos de análise (PS- Buraco da Lama e PS- Saco), sendo ambos na margem da laguna, conforme a localização geográfica na Tabela 1.

Tabela 1: Informações dos pontos amostrais do estudo

\begin{tabular}{cc}
\hline Local & Localização geográfica \\
\hline Palmeiras & $-22.873363,-42.044752$ \\
PS- Buraco da Lama & $-22.876844,-42.053389$ \\
PS- Saco & $-22.878267,-42.053425$ \\
\hline
\end{tabular}

A escolha dos pontos ocorreu através da sugestão de pescadores da Praia do Siqueira. O ponto da análise "Saco", assim conhecido por eles, é o local próximo à saída dos efluentes da estação de tratamento de esgoto e o ponto nomeado "Buraco da Lama" é devido ao fundo do local possuir uma lama fétida e escorregadiça, na qual impede a vara mover a canoa que precisa fixar no solo para impulsionar a locomoção. E o ponto Palmeiras outro bairro a margem da laguna serviu como ponto de referência para as comparações das análises.

\section{Etapas do Trabalho}

a) Medição de parâmetros físico-químicos da água

Para obter informações sobre a qualidade da água, foram feitas análises de amostras de água coletadas em dois pontos na Lagoa de Araruama, no perímetro do bairro Praia do Siqueira e Palmeiras, situados no município de Cabo Frio, no dia 30 no mês de Junho de 2016. Foram realizadas análises físicoquímicas através da sonda multiparâmetro para determinação de: salinidade, $\mathrm{pH}$, condutividade, potencial redox, sólidos totais dissolvidos e temperatura.

b) Coleta de água e análise microbiológica

Foram coletadas amostras de água de apenas um ponto de cada bairro, no qual utilizou de garrafas de polietileno que continham água mineral e após o descarte das mesmas foram novamente preenchidas com as amostras da água dos pontos estudados.

No laboratório do Instituto Federal de Educação, Ciência e Tecnologia Fluminense - IFF Campus Cabo Frio as análises microbiológicas foram refrigeradas, aplicando a metodologia do Número Mais Provável (NMP), foi realizado o teste presuntivo incubando a água em meio Lauril Sulfato Triptona 
(LST) e com tubos de Durham por 24 horas, incubados a $35^{\circ} \mathrm{C}$. Após este período ocorrendo à produção de gás nos tubos de Durham, foi realizado o teste confirmativo de Coliformes termotolerantes utilizando o caldo $E$. coli (EC), com os tubos incubados em $45,5 \stackrel{\circ}{ } \mathrm{C}$ durante 24 horas. O confirmativo para coliformes totais foi conduzido utilizando-se o caldo verde brilhante (VB) a $35^{\circ} \mathrm{C}$ entre 24 48 horas (SILVA et al., 2001, p. 32).

c) Registro fotográfico e relatório de visita guiada

A identificação dos impactos ocorreu por meio de uma visita guiada em uma canoa na laguna com uma pescadora do local. Durante o trajeto foi realizado registros fotográficos e um relatório das informações obtidas.

d) Entrevista direcionada

Após as identificações perceptíveis da visita guiada, foi realizada uma entrevista no mês de Agosto aplicando o método Survey, no qual é utilizado para investigar o que, o porquê, o como ou o quando ocorreu determinada situação (FREITAS, et al., 2000, p. 3).

O questionário foi desenvolvido pelo método Survey classificado como descritiva de corte-transversal e com o público-alvo definido, sendo a população residente no bairro Praia do Siqueira. Freitas et al. (2000, p. 3) define a pesquisa como: descritiva, aquela que busca identificar como a população definida percebe determinada situação e se há variações de percepção, e de cortetransversal por estar relacionado ao tempo da entrevista que, nesse caso foi realizada em um único momento.

A entrevista foi semiestruturada e direcionada para a identificação da importância da laguna para os entrevistados e quais impactos eles identificam que a laguna sofreu. Assim, foi possível a utilização do conceito de percepção ambiental como explica Pacheco et al. (2006, p.4) sobre a consideração de informações que retemos e como são viáveis para transmitir as questões ambientais para o setor responsável proporcionando a democratização da ciência e dos saberes.

Visando a análise de dados suficientes para um melhor resultado qualitativo do método empregado, foi realizado 30 entrevistas in situ de forma aleatória com a comunidade do bairro.

Como garantia de sigilo da informação coletada na entrevista foi entregue um "Termo de Compromisso e Sigilo".

\section{Análises estatísticas}

Os dados coletados através das análises físico-químicas, microbiológica e entrevistas foram organizados em médias e desvios padrões, gráficos de colunas/pizzas e testes estatísticos (ANOVA, complementado com teste Tukey pelo programa Past $3 \AA, p<0,05$ ) utilizando o programa Excel da microsoft ${ }^{\circledR} 2010$. 


\section{Resultados}

\section{Parâmetros físico-químicos e microbiológicos}

O resultado apresentado pelo parâmetro $\mathrm{pH}$ das duas amostras da Praia do Siqueira são ligeiramente mais básica, com 8,21 cada, do que a amostra das Palmeiras, com 8,14 (Figura 2).

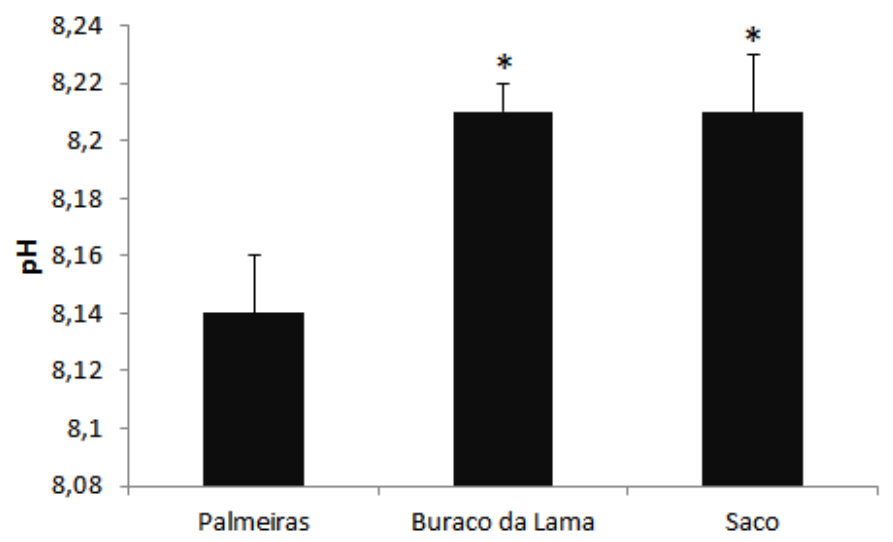

Figura 2: Análise do $\mathrm{pH}$ dos pontos de coleta.

* ANOVA, complementado com teste Tukey usando Palmeiras como referência $(p<0,05)$.

A análise do potencial redox (ORP) apresentou um grande contraste no ponto "Saco" em relação aos outros pontos, com a média das amostras de $-105,10$, enquanto os pontos Palmeiras com 134,4 e "Buraco da Lama" com 130,5 (Figura $3)$.

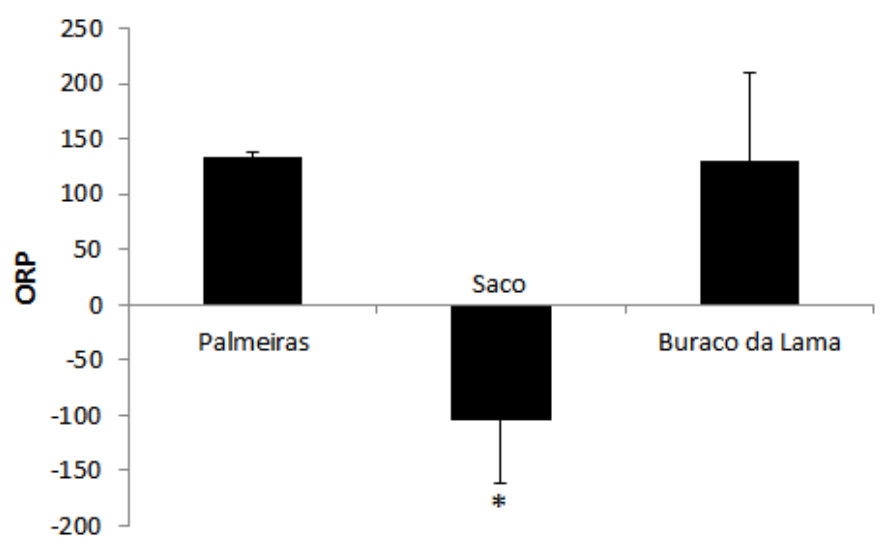

Figura 3: Análise do potencial redox dos pontos de coleta.

* ANOVA, complementado com teste Tukey usando Palmeiras como referência $(p<0,05)$.

As análises dos parâmetros salinidade (PSU) e condutividade apresentaram o desenho do gráfico semelhante, onde os resultados da salinidade foram: Palmeiras com 55,06, "Saco" com 56,36 e "Buraco da Lama" com 55,68, e os resultados das amostras referentes à condutividade foram: 
Palmeiras com 78,46 Ms/cm, "Saco" com 80,46 Ms/cm e "Buraco da Lama" com $79,66 \mathrm{Ms} / \mathrm{cm}$ (Figuras 4 e 5).

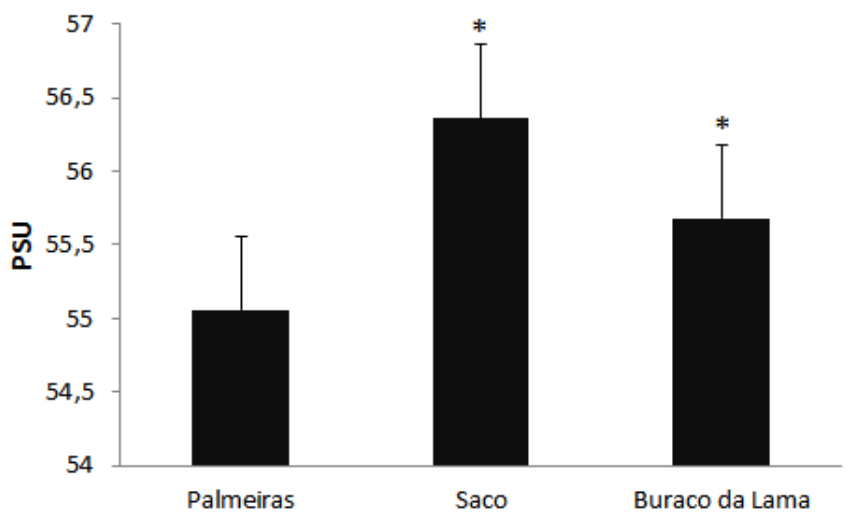

Figura 4: Análise da salinidade dos pontos de coleta.

*ANOVA, complementado com teste Tukey usando Palmeiras como referência $(p<0,05)$.

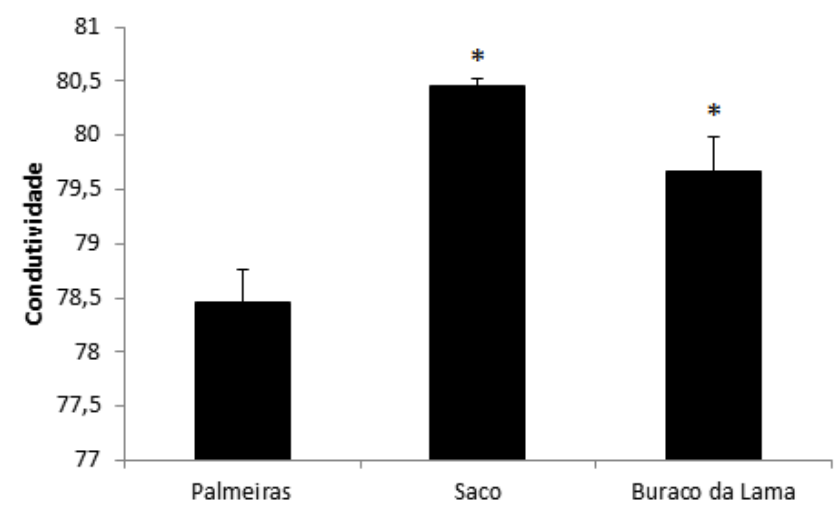

Figura 5: Análise da condutividade em $\mathrm{ms} / \mathrm{cm}$ dos pontos de coleta.

* ANOVA, complementado com teste Tukey usando Palmeiras como referência $(p<0,05)$.

O parâmetro de sólidos totais dissolvidos apresentou um resultado superficialmente maior no "Saco" $(40,25)$ em relação aos outros pontos. Já os pontos Palmeiras com 39,46 e o "Buraco da Lama" com 39,82 (Figura 6).

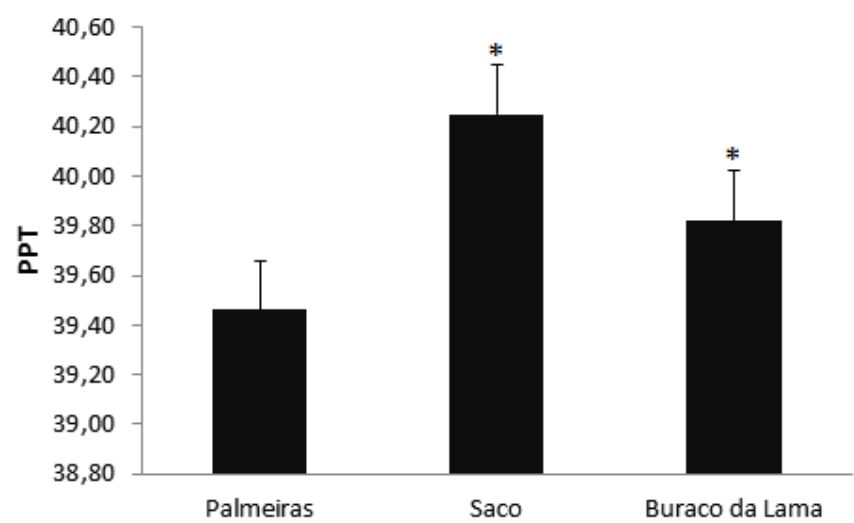

Figura 6: Análise dos sólidos totais dissolvidos dos pontos de coleta.

* ANOVA, complementado com teste Tukey usando Palmeiras como referência $(p<0,05)$. 
A análise da temperatura demonstrou que no "Buraco da Lama" estava menor que nos outros locais com $22,79^{\circ} \mathrm{C}$. Acredita-se que possa ter interferido nesse resultado o fato dessa análise ter sido a primeira análise a ser realizada do dia, e os pontos "Saco" e Palmeiras os resultados foram próximos sendo respectivamente $23,33^{\circ} \mathrm{C}$ e $23,38^{\circ} \mathrm{C}$ (Figura 7 ).

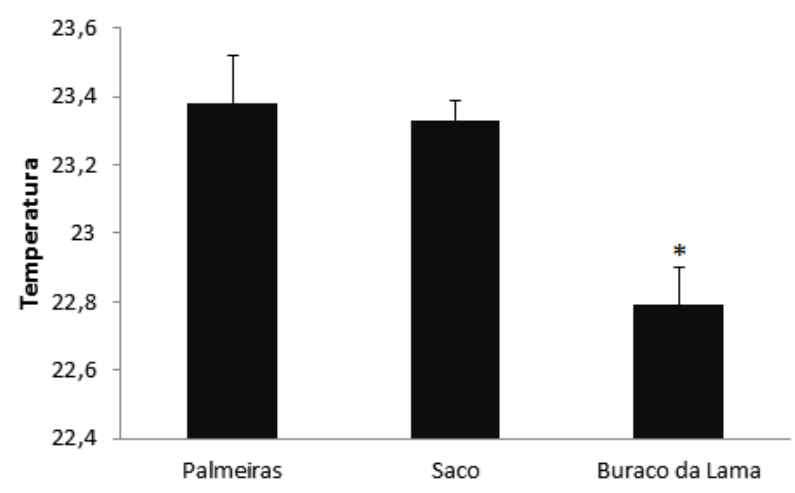

Figura 7: Análise da temperatura em graus Celsius dos pontos de coleta.

* ANOVA, complementado com teste Tukey usando Palmeiras como referência $(p<0,05)$.

Os resultados das análises microbiológicas indicaram a presença de coliformes termotolerantes e coliformes totais significantes na amostra da Praia do Siqueira com 1,5 NMP em cada, e na Palmeiras os coliformes termotolerantes foi de 0,43 NMP e zero de coliformes totais (Figura 8).

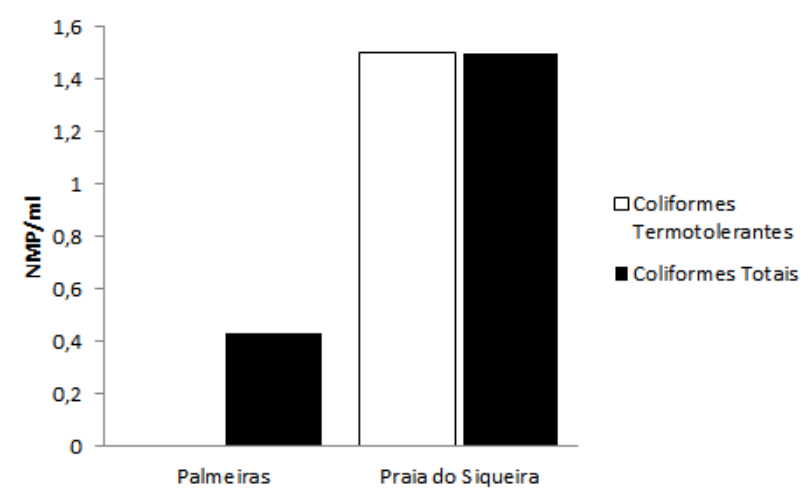

Figura 8: Análise microbiológica das Palmeiras e Praia do Siqueira.

\section{Visita Guiada}

$\mathrm{Na}$ visita guiada (Figura 9) foi visível a dificuldade que os pescadores e moradores da laguna sofrem ao tentarem utilizar o local. Na areia havia cacos de vidro e plásticos, além de algas e lama preta na orla.

Foi mostrada pela guia uma saída de tratamento de esgoto que poderia contribuir com a lama no local a qual dificulta o tráfego das canoas próximo à área. Essa poluição pode causar acidentes com as pessoas que frequentam a 
laguna, além de esteticamente denigrir a paisagem e liberar um odor desagradável com a decomposição das algas, a visita gerou um relatório.

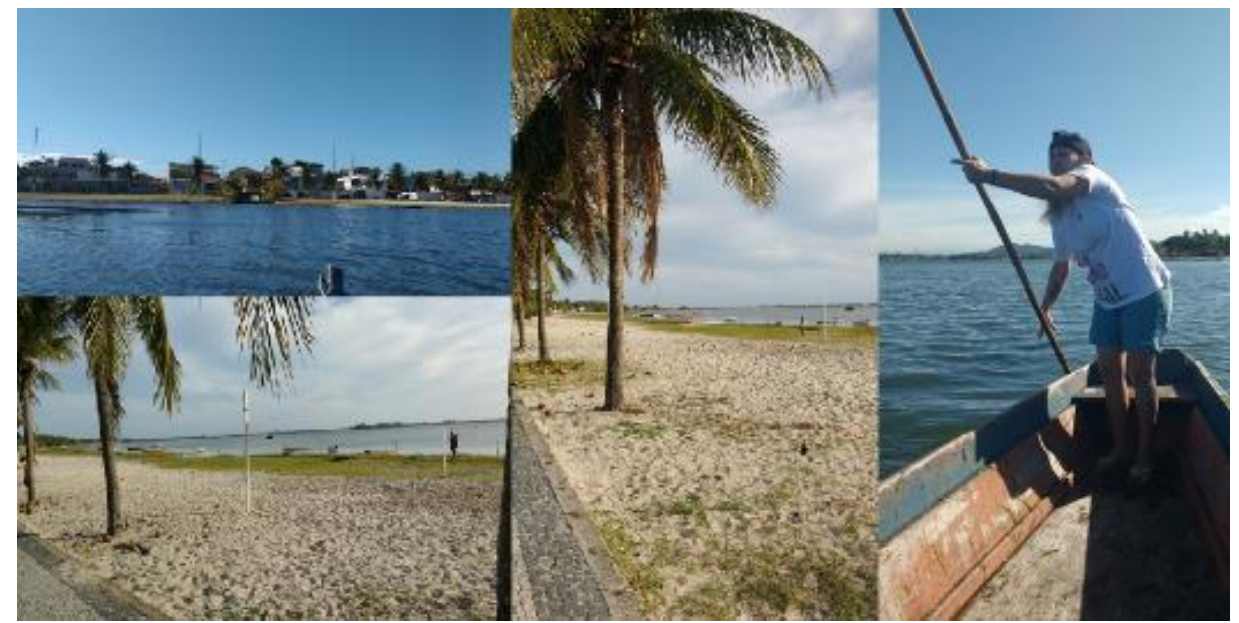

Figura 9: Mosaico de fotos da visita guiada na Praia do Siqueira.

\section{Questionário socioeconômico}

O questionário teve início com uma breve análise do perfil dos respondentes. A primeira questão sobre a idade dos entrevistados foi dividida em faixa etárias seguindo a Lei no 8.069 de 13 de julho de 1990 do Estatuto da Criança e do Adolescente, na qual de 12 a 18 anos de idade são adolescentes (BRASIL, 1990, p. 1). E para complementar foi utilizada a Lei oㅡ 10.741 de 01 de outubro de 2003 do Estatuto do Idoso do qual o agrupamento dos idosos são o das pessoas com 60 ou mais de idade (BRASIL, 2003, p. 1). Sendo assim, estabelecemos que os participantes de 19 a 59 anos de idade ficaram agrupados como "adultos".

O universo de entrevistados por tanto foi maior na faixa etária dos adultos (63\%), seguidos pelos idosos (27\%) e adolescentes (10\%) (Figura 10.1). Já na divisão por sexo as mulheres foram um pouco mais numerosas com $53 \%$ que os homens com 47\% (Figura 10.2).

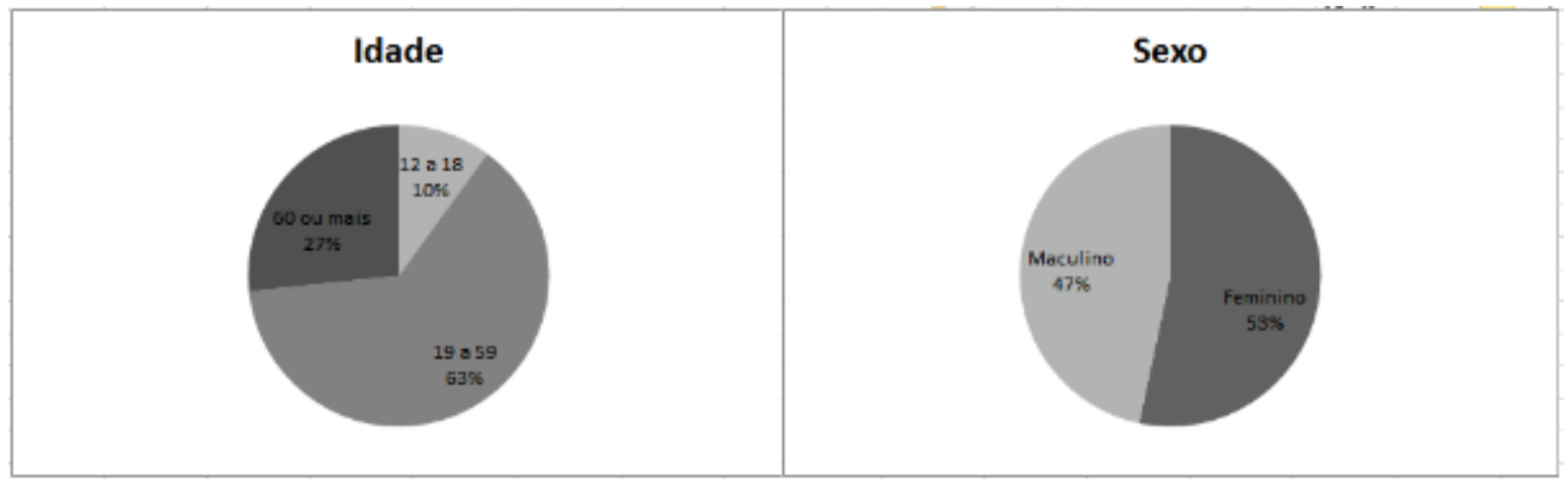

Figura 10.1: Análise da faixa etária de idade.

Figura 10.2: Sexo dos entrevistados.

Na figura 11.1, em relação ao tempo de residência no bairro, foi observado que a maioria dos respondentes reside a mais de 16 anos no local (73\%). E a 
respeito da ocupação diária, a um número um pouco maior são aposentados e do lar (28\% em ambos), e os demais são pescadores (17\%), estudantes (10\%) e outras ocupações (17\%) (Figura 11.2).

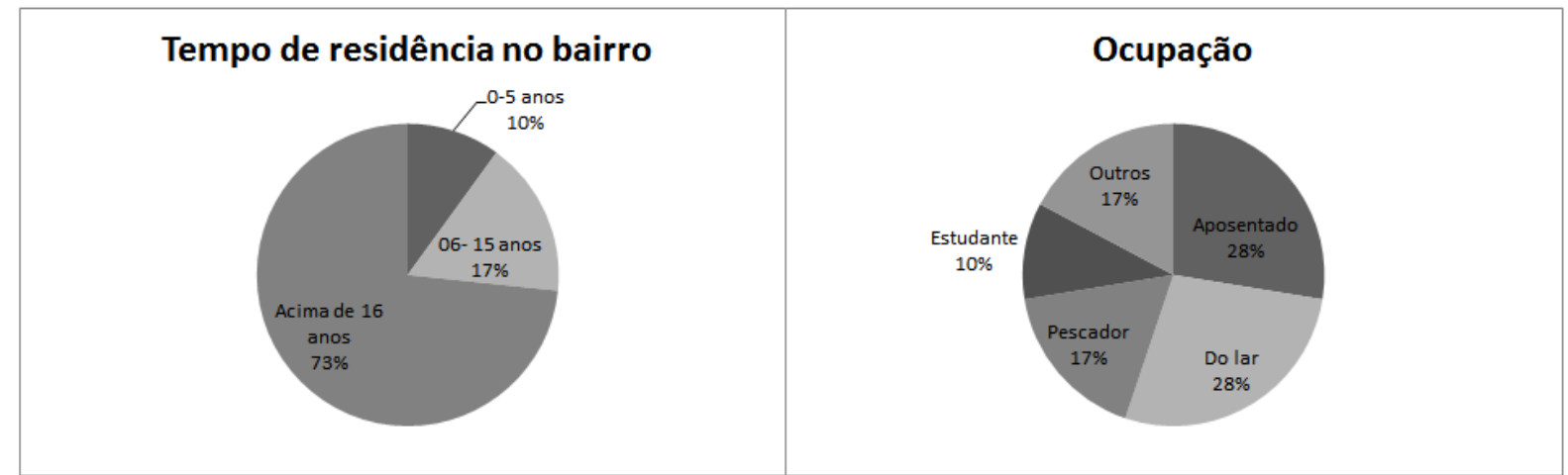

Figura 11.1: Análise do tempo de residência no bairro. Figura 11.2: Ocupação dos entrevistados.

A maior parte dos entrevistados possui água encanada com 97\% (Figura 12.1). Entretanto, o destino do esgoto não é todo direcionado a rede geral (coleta e tratamento do esgoto municipal) apenas $43 \%$, existe ainda o uso de fossas sépticas e de fossa rudimentar cada uma com $10 \%$ de representatividade, e 0 despejo direto na laguna com $7 \%$, sendo que boa parte dos entrevistados desconhecem o destino do seu esgoto (30\%) (Figura 12.2).

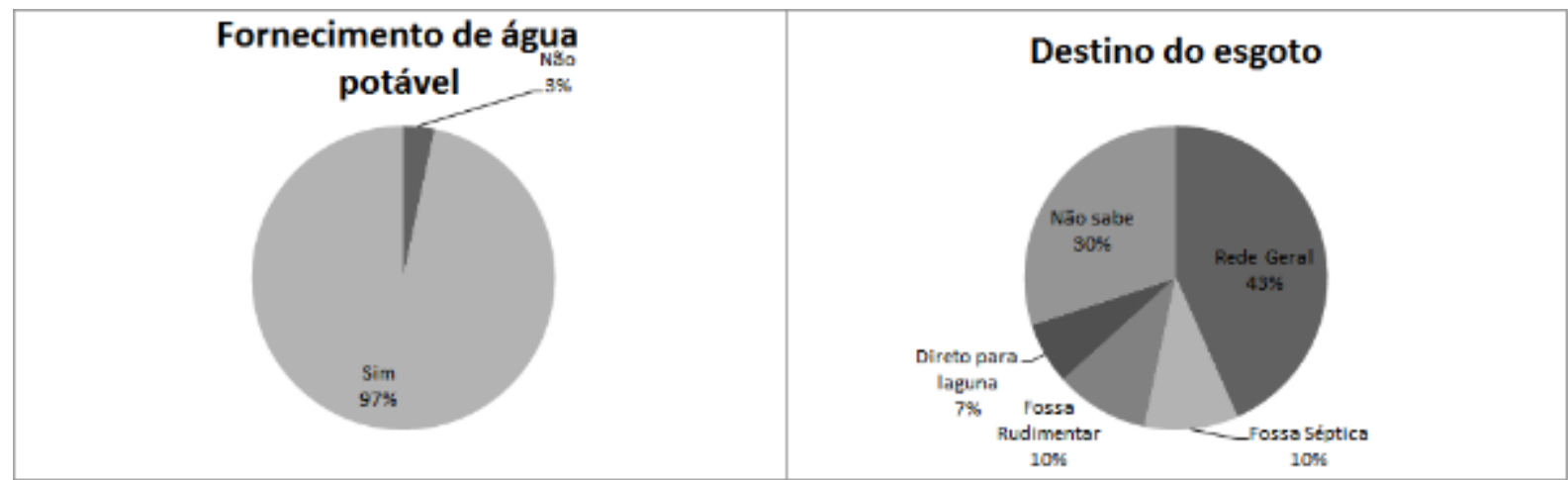

Figura 12.1: Análise da presença de água

Figura 12.2: Destino do esgoto das encanada.

residências dos entrevistados

Para os entrevistados a maior alteração ambiental sofrida na laguna foi ocasionada pela poluição das águas $(64 \%)$, seguida pela pesca predatória (25\%), extração de sal (7\%) e extração de conchas (4\%) (Figura 13.1). Enquanto 
da relação dos mesmos com a laguna, ela ocorre principalmente pelo lazer (61\%) e posteriormente pela pesca (39\%) (Figura 13.2).

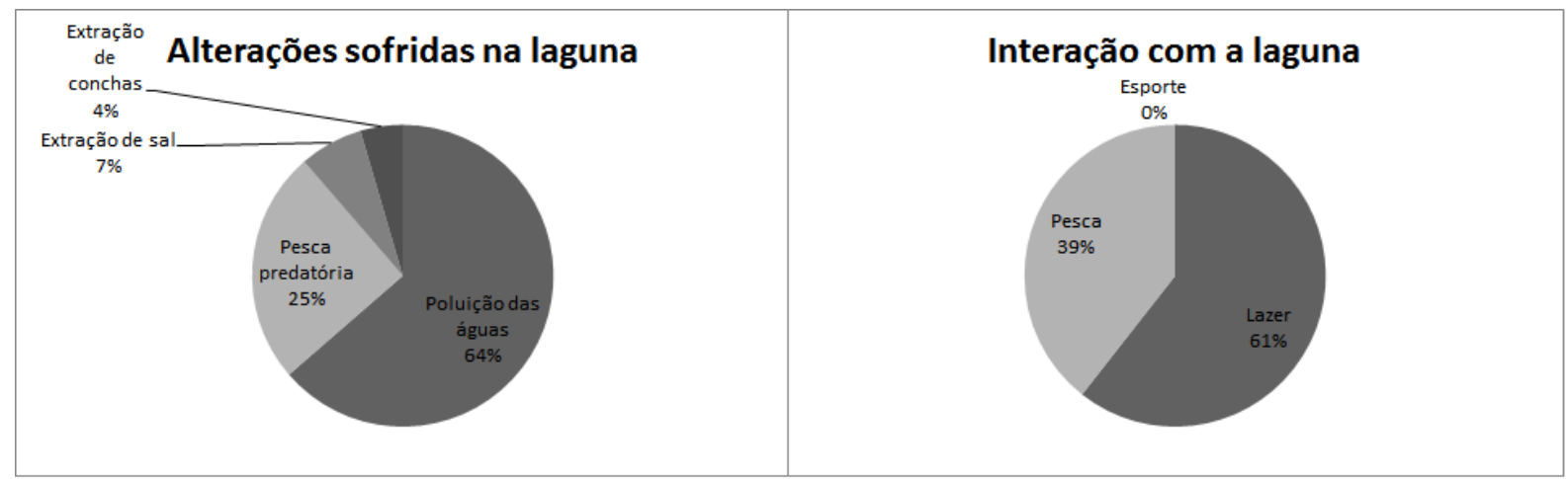

Figura 13.1: Análise das alterações sofridas na laguna.
Figura 13.2: Interação dos entrevistados com a laguna.

A última figura expõe duas questões relacionadas à recuperação da laguna. A questão sobre as ações para recuperar a laguna teve respostas mais relacionadas à fiscalização eficiente no tratamento do esgoto $(37 \%)$, seguido pela conscientização da população (24\%), abertura de outra boca da barra (22\%) e adequação da malha de pesca (16\%) (Figura 14.1). E sobre a adesão em ações que visassem recuperar a lagoa, a maioria gostaria de participar (87\%) (Figura 14.2).

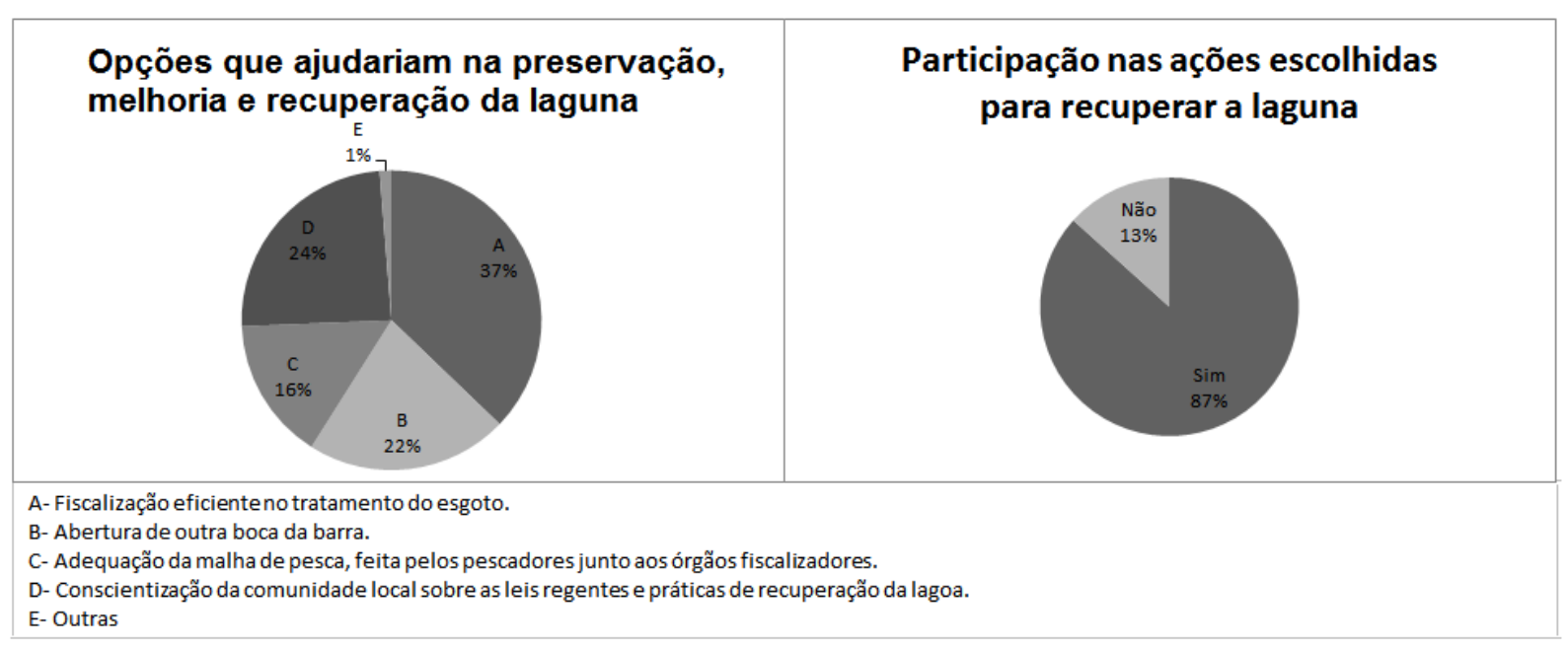

Figura 14.1: Análise sobre as ações de recuperação da laguna.
Figura 14.2: Participação nas ações escolhidas para recuperar a laguna. 


\section{Discussões}

O pH é um parâmetro importante, pois influencia o grau de solubilidade de diversas substâncias na água. Os valores obtidos nos pontos de amostragem em Palmeiras em relação à Praia do Siqueira indicam pequeno aumento, sendo maior o pH da Praia do Siqueira em relação a Palmeiras. O maior tempo de residência da água na Praia do Siqueira contribui para o aumento da quantidade de sais que aumentam a alcalinidade da água. Os valores apresentados em todos os pontos de amostragem são compatíveis com os apresentados em investigações recentes de Rosa et al., (2016, p. 4) e não ultrapassam o limite estabelecido pela Resolução no 357/2005 do CONAMA de pH 8,5 para águas salinas classe 1 (CONAMA, 2005, p. 4).

$O$ potencial redox indica baixas ou altas concentrações de oxigênio na água. Sendo baixo o potencial redox indica queda de oxigênio e alto poder redutivo, podendo estar relacionado ao aporte de efluente com baixa concentração de oxigênio (JARDIM, 2014, p.1). O potencial redox apresentou resultado baixíssimo no ponto "Saco" demonstrando queda nos teores de oxigênio. Tal influência naturalmente deriva da proximidade do ponto da análise com a saída dos efluentes da Estação de Tratamento de Esgoto que é feito pelo sistema de tempo $\operatorname{seco}^{5}$. Em dias de chuva a poluição da laguna aumenta devido a ETE não suportar o volume de água e o efluente é liberado in natura.

A Lagoa de Araruama recebe também diretamente resíduos clandestinos de condomínios residenciais, o despejo irregular de caminhões limpa fossa e a água da chuva no qual alteram suas características originais. No bairro da Praia do Siqueira possui posto de combustível, oficinas de automóveis, faculdade e indústria de sal na qual é desconhecido o descarte dos resíduos gerado por elas.

Em 2015 o secretário de Meio Ambiente de Cabo Frio, relatou em uma entrevista que a Secretária de Meio Ambiente - SEMA estava realizando a vistoria das valas negras e obras de vedação de vala no bairro Palmeiras e Dormitório das Garças, após a elevada floração das algas e ao mau cheiro causado pela decomposição ao longo da orla da Lagoa de Araruama (CRISTIANE, 2015).

No município de Cabo Frio e região a Prolagos, empresa da Aegea, é a concessionária responsável pelos serviços de saneamento básico (implantação dos sistemas de fornecimento, distribuição de água e tratamento de esgoto). $O$ estado através do INEA (Instituto Estadual do Ambiente) e a prefeitura do município possui a responsabilidade de fiscalização das ações da empresa e das irregularidades referentes aos esgotos clandestinos. Porém os esforços já

\footnotetext{
${ }^{5}$ Sistema de tempo seco: compreende na interceptação do esgoto presente nas galerias da rede pluvial, evitando que o mesmo seja despejado in natura no meio ambiente. Disponível em:< http://www.prolagos.com.br/perguntas-e-respostas/> acesso: $31 \mathrm{dez} .2017$
} 
desenvolvidos não estão sendo suficientes para a recuperação da Lagoa de Araruama.

A condutividade elétrica é diretamente proporcional à salinidade, os dois parâmetros são cooperativos, neste sentido os pontos amostrados, a menor salinidade de Palmeiras deve estar relacionada ao aporte de água doce liberado no local. Esteves et al. (2008, p. 970) indicam que os efeitos da salinidade na biodiversidade lagunar local sobre os organismos serem extintos ou a coexistência de espécies dependerão da força em relação ao tempo e espaço.

Quanto ao parâmetro dos sólidos totais dissolvidos presente em praticamente todos os pontos analisados, o resultado foi o esperado devido a presença de efluentes na laguna como é argumentado por Almeida (2013, p. 19) "a existência de sólidos na água pode ocorrer de forma natural (processos erosivos, orgânicos e detritos orgânicos) ou antropogênica (lançamento de lixo e esgoto) ".

Sobre as temperaturas, estas estavam dentro do normal encontrado para a época do ano que foi realizada as análises (ROSA et al., 2016, p. 4).

$\mathrm{Na}$ análise microbiológica foi identificada a presença de coliformes termotolerantes na Praia do Siqueira. Eventualmente, ocorre a liberação de esgoto sem o tratamento adequado pode prejudicar na qualidade da água, como foi apontado nos nossos resultados.

A preocupação com a qualidade da água se torna essencial visto que os entrevistados interagem com a laguna por meio do lazer e da pesca. O pescado capturado por meio da pesca artesanal caracteriza-se pelo consumo próprio, pequena comercialização e recreação (PORCHER et al., 2010, p. 68).

Como verificado em outras situações, a poluição pode ser responsável por causar impacto na qualidade de vida das comunidades que dependem da pesca. Vasconcelos et al. (2012, p. 9) estudaram três comunidades marisqueiras (Apicum, Pirambu e Porto do Mato) em Sergipe e constataram que a poluição de marés, lixo e esgoto, são os principais responsáveis por causarem significativo impacto na geração de renda familiar e na saúde da comunidade. Cabe ressaltar que as três comunidades apresentam problemas de saneamento básico.

Para Rodrigues e Maia (2003, p. 2) quando avaliam os impactos ambientais sobre as comunidades de Aguiraz zona costeira de Fortaleza/CE a ocupação urbana desordenada acrescida da caraterística flutuante desta ocupação marcada pelo turismo e as segundas residências são responsáveis pelos impactos nocivos sobre o meio ambiente. Tal condição é também atribuída aos impactos produzidos no litoral norte do Rio Grande do Sul (MATTOS; GRUBBER, 2011, p. 9).

Ecossistemas frágeis e raros são mais susceptíveis a sofrerem as pressões ambientais deste turismo de veraneio. A lagoa de Araruama é também um bom exemplo de ambiente que não suportou este incremento populacional que a especulação imobiliária vinculada ao turismo de verão promoveu nas 
últimas décadas. Nossos dados comprovam esta afirmação em função do comprometimento da qualidade dos parâmetros analisados.

Em estudo realizado na zona costeira do estado de São Paulo com comunidades de pescadores que utilizam a pesca em pequena escala do camarão sete-barbas (Xiphopenaeus kroyeri) observou-se perda progressiva de territórios de pesca para expansão de outras atividades antrópicas (Portuária, naval, tubulações de petróleo, esgotos) sem nenhum mecanismo compensatório e mitigador baseado em políticas públicas. Demonstrando o cenário típico onde as comunidades de zonas costeiras são submetidas a pressões econômicas e políticas, que ignoram a realidade social e não atendem os objetivos de desenvolvimento sustentável nas zonas marinhas e costeiras (GASALLA; GANDINI, 2016, p. 11). Os autores sugerem o auto-organização das comunidades locais como forma de promover o equilíbrio de forças políticas dentro e fora das áreas marinhas protegidas.

De acordo com a análise do questionário as alterações sofridas na laguna $64 \%$ dos respondentes relataram a poluição da laguna e como ações que ajudariam a preservar, a melhorar e a recuperar a laguna foi destaque com $37 \%$ a fiscalização eficiente no tratamento do esgoto.

As alterações sofridas na laguna ocasionam em impacto ambiental, como é apresentado no artigo primeiro do CONAMA 86 a fim de regularizar os danos causados ao Meio Ambiente caracteriza que:

Art. 1 Para efeito desta Resolução considera-se impacto ambiental qualquer alteração das propriedades físicas, químicas e biológicas do meio ambiente, causada por qualquer forma de matéria ou energia resultante das atividades humanas que, direta ou indiretamente, afetam: I - a saúde, a segurança e o bem-estar da população; II - as atividades sociais e econômicas; III - a biota; IV - as condições estéticas e sanitárias do meio ambiente; $\mathrm{V}$ - a qualidade dos recursos ambientais (CONAMA, 1986, p.1).

Dentre os $97 \%$ respondentes, recebem a água proveniente da fornecedora de água potável na região e apenas $43 \%$ dos entrevistados tem a certeza da liberação do esgoto na rede geral. Essa questão referente ao destino do esgoto se demonstrou mais preocupante quando $30 \%$ dos entrevistados não sabem para onde o seu esgoto vai. Essa informação vai de encontro com a necessidade relatada pelos entrevistados (24\%) da conscientização da comunidade local sobre as leis regentes e práticas de recuperação da laguna a serem realizadas por meio de políticas públicas.

Outra questão que demonstra o interesse na mudança da realidade que hoje se encontra a laguna é que $87 \%$ dos entrevistados gostariam de participar de ações para a recuperação da laguna. 
Esse expressivo interesse na recuperação da Lagoa de Araruama requer de uma implementação da EA, pois permite que os sujeitos envolvidos nas ações ambientais e sociais possam realizá-las de forma democrática, crítica e emancipatória não apenas no contexto comunitário, mas também no ambiente escolar (SILVA et al., 2015, p. 106). Ainda de acordo com Silva et al. (2015, p. 109), a organização e fortalecimento da comunidade se torna essencial para que possam reivindicar seus direitos e cumprirem seus deveres de forma ativa e é fundamental 0 apoio de instituições para desenvolver esse processo com neutralidade, eficiência técnica e política na gestão dos recursos hídricos.

Bertucci et al. (2016, p. 56) relata em sua conclusão que a garantia da utilização social do ambiente, ocorrerá por meio do fortalecimento dos movimentos sociais, das manifestações culturais e a implementação de políticas públicas.

Mediante as análises dos resultados é notória a importância da percepção ambiental a fim de elucidar a ótica científica, social ou política relacionada a este conceito como é discutido em Pacheco et al. (2006, p. 2).

Por outro lado, não poderemos esquecer que estamos diante de um caso típico de injustiça ambiental, segundo a Rede Brasileira de Justiça Ambiental:

O mecanismo pelo qual sociedades desiguais, do ponto de vista econômico e social, destinam a maior carga dos danos ambientais do desenvolvimento às populações de baixa renda, aos grupos sociais discriminados, aos povos étnicos tradicionais, aos bairros operários, às populações marginalizadas e vulneráveis ${ }^{6}$.

Segundo Porto e Pacheco (2009, p. 31) o Brasil apesar do seu relativo desenvolvimento (econômico, industrial e institucional) quando comparado com outros países da América Latina é marcado por forte concentração de renda e poder, possibilitando incontáveis situações de injustiça ambiental. Embora não seja o tema central deste estudo, mas é uma abordagem que vem crescendo no Brasil possibilitando um contraponto a força impositiva do modelo capitalista atual.

\section{Conclusão}

Conforme mostraram os resultados, a Lagoa de Araruama no recorte da Praia do Siqueira, em Cabo Frio, tem sofrido com o impacto ambiental através de alterações na sua característica original, principalmente com a poluição das águas. Tal identificação foi evidenciada nas 4 etapas desenvolvidas na metodologia (físico-química, microbiológica, reconhecimento espacial e percepção da comunidade).

\footnotetext{
6 Disponível em: www.justicaambiental.org.br
}

revista brasileira 
Os pontos de análise na Praia do Siqueira identificados como "Saco" e "Buraco do Lama" são nomes utilizados pelos pescadores do local, realizando assim uma integração do estudo científico ao conhecimento tradicional. Estes nomes vão além da definição de um espaço específico, possuem uma evidência cultural.

Por tanto, de acordo com os dados analisados a laguna necessita de uma atenção maior na qualidade da água, como uma melhor fiscalização no tratamento do esgoto e um trabalho de conscientização da comunidade lagunar.

Diante do estudo exposto, é essencial a elaboração de um projeto de educação ambiental no qual busque a articulação entre o setor privado, o público e sociedade, visando minimizar os impactos identificados, o resgate da Lagoa de Araruama e a melhoraria na qualidade de vida da população. Bem como, fortalecer a organização política da comunidade local para que sejam capazes de reivindicar ações junto ao poder público que atendam as necessidades socioambientais do grupo. Impedindo assim que as pressões econômicas e políticas unicamente determinem o destino dos ambientes costeiros ocupados por estas comunidades.

Para acompanhar as alterações da laguna seria interessante realizar estudos ao longo prazo produzindo um histórico de informações do local e servindo de subsidio a futuros estudos.

\section{Agradecimentos}

A Dra. em Engenharia de Alimentos/UFSC e Prof. a IFF Campus Cabo Frio Adriana Paula Slongo Macussi pela colaboração na análise dos dados biológicos, e ao Doutorando em em Engenharia Ambiental/UERJ e Prof.. IFRJ Campus Arraial do Cabo David Barreto Aguiar pela análise do texto.

\section{Referências}

ALMEIDA, J.C. Avaliação do Índice de Qualidade da Água na lagoa dos Patos. Trabalho de Conclusão de Curso apresentada a Graduação em Engenharia Ambiental e Sanitária. Universidade Federal de Pelotas, Pelotas. 2013. 51p.

BERTUCCI, T.C.P.; SILVA, E.P.; MARQUES JR, A. N.; MONTEIRO NETO, C. Turismo e urbanização: os problemas ambientais da Lagoa de Araruama-Rio de Janeiro. São Paulo: Ambiente \& Sociedade, v.19, n.4, p. 43-64, 2016.

BIDEGAN, P. Lagoa de Araruama: Perfil ambiental do maior ecossistema lagunar hipersalino do mundo. Rio de Janeiro: SEMADS, 2002. $160 \mathrm{p}$.

BERANGER, A.F. Dados históricos do município de Cabo Frio. 3를. Cabo Frio, 500 anos de história. Banco do Brasil, 2003. 103 p.

BRASIL. Dispõe sobre Estatuto da Criança e do Adolescente e dá outras providências, Lei $\mathbf{n}^{\circ}$ 8069. Diário Oficial da União. Brasília, 13 de julho, 1990. 
BRASIL. Política Nacional de Educação Ambiental, Lei $\mathbf{n}^{\circ}$ 9795. Diário Oficial da República Federativa do Brasil. Brasília, 27 de abril, 1999.

BRASIL. Dispõe sobre Estatuto do Idoso e dá outras providências, Lei $\mathbf{n}^{\circ}$ 10741. Diário Oficial da União. Brasília, 03 de outubro, 2003.

CARVALHO, A.P.A.M.; COSTA, R.S.; ROSA, J.C.L. Eutrofização e introdução de espécies exóticas em estuário hipersalino: Lagoa de Araruama, Rio de Janeiro, Brasil. In: IV Seminário Regional Sobre Gestão de Recursos Hídricos Boletim do Observatório Ambiental Alberto Ribeiro Lamego 4., 2014, Campos de Goytacazes. Anais... Rio de Janeiro, Campus Rio Paraíba do Sul - Upea/IFF, 2014. $13 \mathrm{p}$.

CILSJ-CONSÓRCIO INTERMUNICIPAL LAGOS SÃO JOÃO. Plano de Bacia Hidrográfica da Região dos Lagos e do Rio São João. Araruama, 2005. p. 2646.

CONAMA-Conselho Nacional do Meio Ambiente. Resolução CONAMA n. 001 de 17 de fevereiro de 1986. Considerando a necessidade de se estabelecerem as definições, as responsabilidades, os critérios básicos e as diretrizes gerais para uso e implementação da Avaliação de Impacto Ambiental como um dos instrumentos da Política Nacional do Meio Ambiente.

CONAMA- Conselho Nacional de Meio Ambiente. Resolução no 357 de 17 de março de 2005. Dispõe sobre a classificação dos corpos de água e diretrizes ambientais para o seu enquadramento, bem como estabelece as condições e padrões de lançamento de efluentes, e dá outras providências.

CRISTIANE, R. Após críticas relativas à poluição da lagoa em Cabo Frio Sema mostra trabalho de saneamento. RC24H, 2015. Disponível em: <http://rc24h.com.br/noticias/ver/18005/>. Acesso em: 29 de dez. 2017.

DIAS, G.F. Educação Ambiental: Princípios e Práticas. $9^{\circ}$ Ed. São Paulo: Gaia, 2004. $541 \mathrm{p}$.

ESTEVES, F.A.; CALIMAN, A.; SANTANGELO, J.M.; GUARIENTO, R.D.; FARJALLA, V.F.; BOZELLI, R.L. Neotropical coastal lagoons: an appraisal of their biodiversity, functioning, threats and conservation management. Brazilian Journal of Biology, v.68, n.4, p. 967-981, 2008.

FERREIRA, N.V.S. PESoa: programa de educação socioambiental. Anais do II Fórum Ambiental da Alta Paulista. São Paulo: ANAP, 2006.

FREITAS H.; OLIVEIRA M.; SACCOL A.Z.; MOSCAROLA J. O método de pesquisa Survey. São Paulo: Revista de Administração da USP, v.35, n.3, p. 105-112, 2000.

GASALLA, M.A.; GANDINI, F.C. The loss of fishing territories in coastal areas: the case of seabob-shrimp small-scale fisheries in São Paulo, Brazil. Maritime Studies (2016) vol.15, n.9., p.1-18, 2016.

JARDIM, W.F. Medição e interpretação de valores do potencial redox (E H) em matrizes ambientais. São Paulo: Química Nova, v.37, n.7, p. 1233-1235, 2014.

revista brasileira educação ambiental 
LIMA, C.A.I.; VIEGAS, M.O.; BERNSTEIN, A. O impacto da urbanização em lagoas do Rio de Janeiro: estudo de caso sobre as lagoas Rodrigo de Freitas e de Araruama. Rio de Janeiro: Revista Educação Pública, 2014.

LOUREIRO, C.F.B. Sustentabilidade e educação: um olhar da ecologia política. São Paulo: Cortez, 2012. 128p.

MATOS, E.A.C.; GRUBER, N.L.S. Os Efeitos Da Atividade Turística No Litoral Norte Do Rio Grande Do Sul. Porto Alegre: Para Onde!?. v. 3, n. 2, ago. 2011. Disponível em:<http://seer.ufrgs.br/index.php/paraonde/article/view/22102>. Acesso em: 31 dez. 2017.

MOREIRA, A.L.C. A eutrofização na Lagoa de Araruama e o impacto ambiental das estações de tratamento secundário. Ambiente Brasil, 2017. Disponível em: $<$ http://ambientes.ambientebrasil.com.br/agua/artigos agua salgada/a eutrofiz acao na lagoa de araruama e o impacto ambiental das estacoes de trat amento secundario.html>. Acesso em: $28 \mathrm{dez}$. 2017. 4p.

PACHECO, E.; SILVA, H.P. Compromissos epistemológicos do conceito de percepção ambiental. Anais do II Seminário de Áreas protegidas e Inclusão Social. Rio de Janeiro: EICOS, 2006.

PEREIRA, L.F.M. A gestão participativa no caso do saneamento da região dos lagos, Rio de Janeiro. Florianópolis: Revista Discente Expressões Geográficas, n.3 p. 20-40, 2007.

PORCHER, L.C.F.; POESTER, G.; LOPES, M.; SCHONHOFEN, P.; SILVANO, R.A.M. Percepção dos moradores sobre os impactos ambientais e as mudanças na pesca em uma lagoa costeira do litoral sul do Brasil. São Paulo: Boletim do Instituto de Pesca, v.36, n.1, p. 61-72, 2010.

PORTO, M.F.; PACHECO, T. Conflitos e injustiça ambiental em saúde no Brasil. Brasília: Tempus Actas em Saúde Coletiva, v. 4, n. 4, p. 26-37, 2009.

RIBEIRO, B.L.; CHAGAS, L.A.; RAMALHO, R.S.; RIVERA, P.V.P.R.; PACHECO, R.T. Geografia e pesca: diagnóstico socioambiental da comunidade pesqueira artesanal de Cabo Frio/RJ. Anais do XVI Encontro Nacional dos Geógrafos. Porto Alegre: ENG, 2010.

ROSA, J.C.L.; ALBERTO, M.D.; RIBAS, W.M.M.; NEVES, M.H.C.B.; FERNANDES, L.D.A. Spatial variability in the icthyoplankton structure of a subtropical hypersaline lagoon. São Paulo: Brazilian Journal of Oceanography, v. 64, n. 2, p. 149-156, 2016.

RODRIGUES, R.A.; MAIA, L.P. Impactos ambientais na zona costeira e a qualidade de vida das comunidades. In: IX Congresso da Associação Brasileira de Estudos do Quaternário/ll Congresso do Quaternário de Países de Línguas lbéricas/II Congresso sobre Planejamento e Gestão da Zona Costeira dos Países de Expressão Portuguesa. Recife, 2003. Publicação em CD Rom. São Paulo, Associação Brasileira de Estudos do Quaternário. Disponível em: $<$ http://www.abequa.org.br/trabalhos/sensoriamento 337.pdf>. Acesso: $30 \mathrm{dez}$. 2017. 
SOUZA, B.C.P. et al. A Cartografia Histórica e os nomes geográficos: uma análise dos geônimos de Cabo Frio - RJ. Anais do I Simpósio Brasileiro de Cartografia Histórica. Paraty: CRCH da UFMG, 2011.

SILVA N.; JUNQUEIRA V.C.A.; SILVEIRA N.F.A. Manual de Métodos de Análise Microbiológica de Alimentos. $2^{\circ}$ Ed. São Paulo: Varela, 2001. 317p.

SILVA, N.R. Caracterização das relações socioeconômicas da cadeia produtiva da pesca em Macaé - RJ: transformações e impactos associados à economia do petróleo. Dissertação apresentada ao Programa de Pós-graduação em Engenharia Ambiental. Instituto Federal de Educação, Ciência e Tecnologia, 2013, 76p.

SILVA, T.K.F.; Ó, C.M.; FARIAS, C.R.O. Percepções de um conflito socioambiental e suas contribuições para Educação Ambiental. Rio Grande: Revista de Educação Ambiental, v.20, n.1 p.104-122, 2015.

VASCONCELOS, L.C.; ARANHA, M.L.M.; LIMA, S.V.N. Trabalho, meio ambiente e saúde em comunidades marisqueiras de Sergipe. Anais do VI Colóquio Internacional de Educação e Contemporaneidade. São Cristóvão Sergipe, 2012.

Disponível em:<http://educonse.com.br/2012/eixo 19/PDF/29.pdf> Acesso: 30 dez. 2017. 